\title{
Correlation of Tensile Strength of Split Cylinder Test and Double Punch Test of a Rubberized Asphalt Concrete Used in Flexible Pavement Design
}

\author{
Enwuso A. Igwe ${ }^{1}$, Emmanuel O. Ekwulo ${ }^{2}$, Captain G. Ottos ${ }^{3}$ \\ Department of Civil Engineering, Rivers State University of Science and Technology, \\ Nkpolu Oroworukwo, Port Harcourt, Rivers State, Nigeria
}

\begin{abstract}
Asphalt concrete mixtures are usually used synonymously in the study and analysis flexible pavements. However, the make-up of flexible pavement is one that is both composite and complicated and therefore requiring characterization of these materials and the pavement as a whole. The term characterization of pavement materials refers to the evaluation of the properties of the individual materials that make up the pavement. Also, it includes evaluating the properties of the pavement as a conglomerate such that its performance during use is sufficient to sustain the various loading conditions (traffic, thermal, moisture, wind etc) during the design period without deterioration, deformation or failure. Thus, the present study focused on two important characterization procedures (split cylinder and double punch tests) for characterizing flexible pavement with the objective of determining a correlation between them for a rubberized asphalt concrete mix. The result revealed that tensile strength for a split cylinder test can actually be predicted from a double punch test under varying rubber latex addition. Results further reveal that their correlation is excellent with an $R^{2}$ of 1 .
\end{abstract}

Keywords: Correlation, Tensile Strength, Split Cylinder, Double Punch, Rubberized Concrete \& Flexible Pavement

\section{INTRODUCTION}

It is common knowledge amongst highway engineers that flexible pavements are easily simulated in the laboratory using asphaltic or bituminous mixtures. Therefore, the performance of bituminous mixtures in the laboratory can be used to predict the behavior of flexible pavements under similar conditions. However, in reality the prediction of the performance of flexible pavement under service condition is one that is challenging to highway engineers due mainly to non-homogeneity of the material make up of the pavement, irregular vehicular loading sand varying environmental conditions such as temperature, moisture and oxidation rates (Igwe et al., 2009). All of these challenges further buttress the importance of material characterization.

The tensile strength of concrete is usually determined from indirect tensile tests (splitting tests on cylinders) rather than from direct pull tests on briquettes or from flexural tests on beams although flexural tests are valuable in connection with road and runway work (Chen and Yuan 1995). In countries where the compressive strength of concrete is determined from cubes rather than from cylinders, the tensile strengths have been obtained using a split cube or a cube specimen tested diagonally.

The drawbacks of direct pull tests include the difficulty in eliminating eccentricity of the line of action of the load and the development of stress concentrations near the gripping devices (Chen and Yuan 1980; and Emesiobi, 2000).

There are various types of tests that are used for material characterization. Examples include - simple flexural beam fatigue test in third point loading of rectangular specimens cantilever-type loading of trapezoidal specimens (Bonnot 1986) and diametral loading in indirect tensile mode (Said, 1998). According to Mallick and El-Korchi 2013: p280, the Indirect Tensile test by splitting cylindrical specimens is one of the three most important tests used in material characterization of hot mix asphalt concretes (HMA) which simulate flexible pavements. 
According to Chen and Yuan (1980) indirect tensile tests are the most attractive because they enable similar specimens, and the same testing machine, to be used for both tensile and compressive strength tests. In addition, indirect tensile tests on cylinders give more consistent results with the measured strengths being between those of the other two tests. An appraisal of the splitting tests on cylinders has been given by Wright (1955) and splitting tests on cube specimens have been described by Nilsson (1961). Techniques used for the determination of tensile strengths have also been discussed thoroughly by Malhotra (1967). An analytical study using a finite element method for various splitting tests has been reported previously by Davies and Bose (1968). A formula for computing the tensile strength of indirect tensile tests has been obtained from the theory of linear elasticity (Timoshenko, 1934) and a plasticity treatment of this problem has been proffered by Chen (1968). It is found that the result derived from the theory of perfect plasticity is identical to that derived from the theory of linear elasticity. The success in applying the theory of perfect plasticity to the problem of the indirect tensile test suggests an alternative new testing technique for the determination of the tensile strength of concretes (Chen and Yuan 1980).

On the other hand Chen (1970) proposed the double punch test as an indirect method for determining tensile strength of concretes. His study has thus been extended to use for determining tensile strength of asphalt concrete mixtures synonymous with flexible pavements for material characterization.

In this test, a concrete cylinder is placed vertically between the loading platens of the test machine and compressed by two steel punches located concentrically on the top and bottom surfaces of the cylinder. It is observed that, although the specimen splits across the vertical diametric plane in a manner exactly similar to that observed in an indirect tensile test; the necessary test arrangement in obtaining the tensile strength of concrete may be reduced (Chen, 1968).

\subsection{Objective}

The objective of the research study was to develop a correlation between tensile strength from a double punch test with tensile strength from a typical split cylinder test for a rubberized asphalt concrete mixture used synonymously in analysis of flexible pavements.

\section{Materials ANd Methods}

\subsection{Sample Collection}

The materials used for this study were rubber latex, bitumen, coarse and fine aggregates. The rubber latex used was obtained from Ikot Essien in Ibiono Ibom Local Government Area of Akwa Ibom State in Nigeria while the bitumen used was collected from the Federal Ministry of Works in Rivers State, Nigeria. Commercial aggregates were, however, used. After sampling of the materials, laboratory tests - specific gravity, grading of bitumen and sieve analysis of the aggregates used for mixproportioning by straight line method were carried out.

\subsection{Sample Preparation}

Samples were prepared using Marshal Design Procedures for asphalt concrete mixes as presented in Asphalt Institute (1981), National Asphalt Pavement Association (1982) and Roberts et al (1996). The procedures involved the preparation of a series of test specimens for a range of asphalt (bitumen) contents such that test data curves showed well defined optimum values. Tests were scheduled on the bases of 0.5 percent increments of asphalt content with at least 3 -asphalt contents above and below the optimum asphalt content. In order to provide adequate data, three replicate test specimens were prepared for each set of asphalt content used. During the preparation of the unmodified asphalt concrete samples, the aggregates were first heated for about 5 minutes before bitumen was added to allow for absorption into the aggregates. After which the mix was poured into a mould and compacted on both faces with 35 blows using a $6.5 \mathrm{~kg}$-rammer falling freely from a height of $450 \mathrm{~mm}$. Compacted specimens were subjected to density and voids analysis to determine optimum asphalt content.

On the other hand the rubberized asphalt concrete samples were prepared under similar conditions as afore however, with additions of rubber latex at optimum asphalt content at varying amounts 0.5 $3 \%$. Results obtained were then subjected to tensile strength tests using split cylinder and double punch testing techniques. 


\subsection{Indirect Tensile Test using Split Cylinder}

The tensile characteristics of bituminous mixtures were evaluated by loading the Marshall specimen along a diametric plane with a compressive load at a constant rate acting parallel to and along the vertical diametrical plane of the specimen through two opposite loading strips. This loading configuration developed a relatively uniform tensile stress perpendicular to the direction of the applied load and along the vertical diametrical plane, ultimately causing the specimen being tested to fail by splitting along the vertical diameter.

A $13 \mathrm{~mm}\left(1 / 2^{\prime \prime}\right)$ wide strip loading was used for $102 \mathrm{~mm}$ diameter and $64 \mathrm{~mm}$ thick specimen to provide a uniform loading with which produced a nearly uniform stress distribution. The static indirect tensile strength of each specimen was determined using the procedure outlined in ASTM D 6931 were a loading rate of $51 \mathrm{~mm} /$ minute was adopted causing Tensile failure to occur in the sample rather than the compressive failure. Plywood strips were used so that the load is applied uniformly along the length of the cylinder. The compressive load indirectly created tensile load in the horizontal direction of the sample and the peak load at failure of specimen was recorded and was divided by appropriate geometrical factors to obtain the split tensile strength. The theoretical basis for computing the tensile strength of a split cylinder test has been derived from the theory of linear elasticity (Timoshenko, 1934: pp.104-108) for a solid disc as shown below using equation 1:

$$
S_{T}=\frac{2 P}{\pi T D}
$$

The theoretical basis for computing the tensile strength of a split cylinder test has been derived from the theory of linear elasticity (Timoshenko, 1934: pp.104-108).

Where;

$S_{\mathrm{T}}=$ Tensile Strength from split cylinder test $-\mathrm{N} / \mathrm{mm}^{2}$

$\mathrm{P}=$ Maximum load at failure, $\mathrm{N}$

$t=$ specimen height immediately before test, $\mathrm{mm}$

$D=$ specimen diameter, $\mathrm{mm}$

The procedure was repeated for rubber latex modified bituminous concretes at varying amounts between $0.5-3.0$ percent rubber latex content and peak loads measured at failure to ascertain the effect of rubber latex additions on the indirect tensile strengths of the mixtures.

\subsection{Double Punch Test}

The test was performed by loading concentrically an asphalt concrete cylinder of $64 \mathrm{~mm}$ height and $102 \mathrm{~mm}$ diameter top and bottom using two cylindrical steel punches of $25 \mathrm{~mm}$ diameter at a rate of $25 \mathrm{~mm} /$ minute until failure occurred. The applied load generated an almost uniform tensile stress across the vertical planes containing the load causing the specimen to split across the planes similar to that of the split cylinder test. The tensile strength was computed by adopting the equation developed by (Chen, 1969) as follows:

$$
f_{t}=\frac{Q}{\pi\left(1.2 b H-a^{2}\right)}
$$

Where;

$$
\begin{aligned}
& f_{t}=\text { Tensile Strength from double punch test }-\mathrm{N} / \mathrm{mm}^{2} \\
& \mathrm{Q}=\text { maximum load at failure } \\
& \mathrm{a}=\text { radius of punch }=12.5 \mathrm{~mm} \\
& \mathrm{~b}=\text { radius of specimen }=51 \mathrm{~mm} \\
& \mathrm{H}=\text { height of specimen }=64 \mathrm{~mm}
\end{aligned}
$$


Enwuso A. Igwe et al.

\section{Results (TABles 1-6 \& Figures 1 - 3)}

The results from the laboratory and analysis of the results are presented in the tables and figure below;

Table1. Laboratory test results of stated materials

\begin{tabular}{|l|l|l|l|l|}
\hline Material & Rubber & asphalt & Sand & Gravel \\
\hline Specific gravity & 0.90 & 1.36 & 2.66 & 2.90 \\
\hline Grade of binder material & - & $40 / 50$ & - & - \\
\hline Mix proportion (\%) & - & - & 42 & 58 \\
Viscosity of binder (poise) & - & $0.45^{*}\left(10^{-6}\right)$ & - & - \\
Softening point & - & $48^{\circ} \mathrm{C}$ & - & - \\
Penetration value & - & $44 \mathrm{~mm}$ & - & - \\
& & & & \\
\hline
\end{tabular}

Table2. Schedule of Aggregates used for mix proportion

\begin{tabular}{|l|l|l|l|l|}
\hline $\begin{array}{l}\text { Sieve size } \\
(\mathbf{m m})\end{array}$ & $\begin{array}{l}\text { Specification } \\
\text { limit }\end{array}$ & $\begin{array}{l}\text { Aggregate A } \\
\text { (Sand) }\end{array}$ & $\begin{array}{l}\text { Aggregate B } \\
\text { (Gravel) }\end{array}$ & $\begin{array}{l}\text { Mix proportion } \\
(\mathbf{0 . 4 2 A + 0 . 5 8 B})\end{array}$ \\
\hline 19.0 & 100 & 100 & 100 & 100 \\
\hline 12.5 & $86-100$ & 100 & 97 & 98 \\
\hline 9.5 & $70-90$ & 100 & 62 & 78 \\
\hline 6.3 & $45-70$ & 100 & 26 & 57 \\
\hline 4.75 & $40-60$ & 99 & 10 & 47 \\
\hline 2.36 & $30-52$ & 96 & 0 & 40 \\
\hline 1.18 & $22-40$ & 90 & 0 & 38 \\
\hline 0.6 & $16-30$ & 73 & 0 & 31 \\
\hline 0.3 & $9-19$ & 23 & 0 & 10 \\
\hline 0.15 & $3-7$ & 3 & 0 & 1.26 \\
\hline 0.075 & 0 & 0 & 0 & 0 \\
\hline
\end{tabular}

Table3. Tensile Strength from Split Cylinder Test for Pure HMA (0\% Rubber) and Rubberized Asphalt Concrete (0.5-3\% Rubber)

\begin{tabular}{|l|l|l|l|l|}
\hline $\begin{array}{l}\text { Rubber Latex Content } \\
(\%)\end{array}$ & $\begin{array}{l}\text { Peak Load at Failure } \\
(\mathbf{N})\end{array}$ & $\begin{array}{l}\mathbf{T} \\
(\mathbf{m m})\end{array}$ & $\begin{array}{l}\mathbf{D} \\
(\mathbf{m m})\end{array}$ & $\begin{array}{l}S_{T}=\frac{2 P}{\pi t d} \\
\left(\mathbf{N} / \mathbf{m m}^{2}\right)\end{array}$ \\
\hline 0.0 & 1520 & 64 & 102 & 0.148213 \\
\hline 0.5 & 2326 & 64 & 102 & 0.226805 \\
\hline 1.0 & 2941 & 64 & 102 & 0.286773 \\
\hline 1.5 & 3290 & 64 & 102 & 0.320804 \\
\hline 2.0 & 1551 & 64 & 102 & 0.151236 \\
\hline 2.5 & 1451 & 64 & 102 & 0.141485 \\
\hline 3.0 & 321 & 64 & 102 & 0.0313 \\
\hline
\end{tabular}

Table4. Tensile Strength from Double Punch Test for Pure HMA (0\% Rubber) and Rubberized Asphalt Concrete (0.5-3\% Rubber)

\begin{tabular}{|l|l|l|l|l|l|}
\hline $\begin{array}{l}\text { Rubber Latex } \\
\text { Content } \\
(\boldsymbol{\%})\end{array}$ & $\begin{array}{l}\text { Peak Load at } \\
\text { Failure } \\
(\mathbf{N})\end{array}$ & $\begin{array}{l}\text { a - radius } \\
\text { of punch } \\
(\mathbf{m m})\end{array}$ & $\begin{array}{l}\text { b-radius of } \\
\text { specimen } \\
(\mathbf{m m})\end{array}$ & $\begin{array}{l}\mathbf{H} \text {-height of } \\
\text { specimen } \\
(\mathbf{m m})\end{array}$ & $\begin{array}{l}f_{t}=\frac{Q}{\pi\left(1.2 b H-a^{2}\right)} \\
\left(\mathbf{N} / \mathbf{m m}^{2}\right)\end{array}$ \\
\hline 0.0 & 1520 & 12.5 & 51 & 64 & 0.128642965 \\
\hline 0.5 & 2326 & 12.5 & 51 & 64 & 0.196857589 \\
\hline 1.0 & 2941 & 12.5 & 51 & 64 & 0.24890721 \\
\hline 1.5 & 3290 & 12.5 & 51 & 64 & 0.278444311 \\
\hline 2.0 & 1551 & 12.5 & 51 & 64 & 0.131266604 \\
\hline 2.5 & 1451 & 12.5 & 51 & 64 & 0.122803251 \\
\hline 3.0 & 321 & 12.5 & 51 & 64 & 0.027167363 \\
\hline
\end{tabular}

\section{Developing a Model Fit}

The researchers have assumed that the model fit between tensile strength from the double punch test and tensile strength from split cylinder test is of the form as shown in equation 3 below which was validated as would been seen in later below; 


$$
S_{T}=a *\left(f_{t}\right)^{E X P(b)}
$$

Where,

$\mathrm{S}_{\mathrm{T}}=$ Tensile strength from split cylinder $-\mathrm{N} / \mathrm{mm}^{2}$

$f_{t}=$ Tensile Strength from double punch test $-\mathrm{N} / \mathrm{mm}^{2}$

$a$ and $b$ are statistically determined coefficients

\subsection{Non Linear Model Syntax}

A non linear model is one in which at least one of the parameters appear nonlinearly (Serber and Wild, 1989; Ratkowsky, 1990; and Draper and Smith, 1998). More formally, in a nonlinear model, at least one derivative with respect to a parameter should involve that parameter. To solve the non linear regression using SPSS the variables were first collated into different cells in the "DATA VIEW" dialogue box. Next these variables were stringed and coded into another dialogue box called the "VARIABLE VIEW CELL". Finally, model syntax was developed that satisfies the condition of the initially assumed general form of the proposed comparative model. The non linear model syntax is of the form as shown below;

$$
S_{T}=a *\left(f_{t} * * \exp b\right)
$$

Equation 4 is the non linear syntax model that corroborates the general form of the assumed model fit between the tensile strength from double punch test and tensile strength from split cylinder test used in the SPSS program. Furthermore, the command $(* *)$ means raising a variable to the power of the coefficient in the same bracket while the command $(*)$ means multiplication.

\section{ReSUlts}

By applying equation 4 in the SPSS program the statistical coefficients a and $b$ were determined as follows; (see Appendix A: Tables 1-3 for iteration history of coefficients).

Table5. Model Coefficients and $R^{2}$

\begin{tabular}{|l|l|}
\hline Coefficients & value \\
\hline $\mathrm{a}$ & 1.152 \\
\hline $\mathrm{b}$ & $2.3 * \operatorname{Exp}(-6)=0.005701$ \\
\hline $\mathrm{R}^{2}$ & 1 \\
\hline
\end{tabular}

By inputting the resulting coefficients into equation (3) above we have the resulting comparative model;

$$
S_{T}=1.152 *\left(f_{t}\right)^{\operatorname{EXP}(2.3 \operatorname{EXP}(-6))}
$$

Solving the numerical value for $\mathbf{b}=0.005701$. Therefore, the resulting model will be of the form; $S_{T}=1.152 *\left(f_{t}\right)^{\operatorname{EXP}(0.005701)}$

\section{VALIDATION OF RESULTS}

The model developed was validated by inputting values of tensile strength from double punch test into equation 6 and comparing with the measured values of tensile strength from split cylinder test.

Table6. Comparative Results from Model Fit

\begin{tabular}{|l|l|l|l|}
\hline $\begin{array}{l}\text { Rubber } \\
\text { Latex } \\
\begin{array}{l}\text { Content } \\
(\%)\end{array}\end{array}$ & $\begin{array}{l}S_{T}=\frac{2 P}{\pi t d} \\
\left(\mathbf{N} / \mathbf{m m}^{2}\right) \\
\text { Measured values }\end{array}$ & $\begin{array}{l}S_{T}=1.152 *\left(f_{t}\right)^{E X P(0.005701)} \\
\left(\mathbf{N} / \mathbf{m m}^{2}\right) \\
\text { Predicted values }\end{array}$ & $\begin{array}{l}f_{t}=\frac{Q}{\pi\left(1.2 b H-a^{2}\right)} \\
\left(\mathbf{N} / \mathbf{m m}^{2}\right)\end{array}$ \\
\hline 0.0 & 0.148213 & 0.146342 & 0.128642965 \\
\hline 0.5 & 0.226805 & 0.226583 & 0.196857589 \\
\hline 1.0 & 0.286773 & 0.285505 & 0.24890721 \\
\hline 1.5 & 0.320804 & 0.320489 & 0.278444311 \\
\hline 2.0 & 0.151236 & 0.151088 & 0.131266604 \\
\hline 2.5 & 0.141485 & 0.141347 & 0.122803251 \\
\hline 3.0 & 0.0313 & 0.03127 & 0.027167363 \\
\hline
\end{tabular}




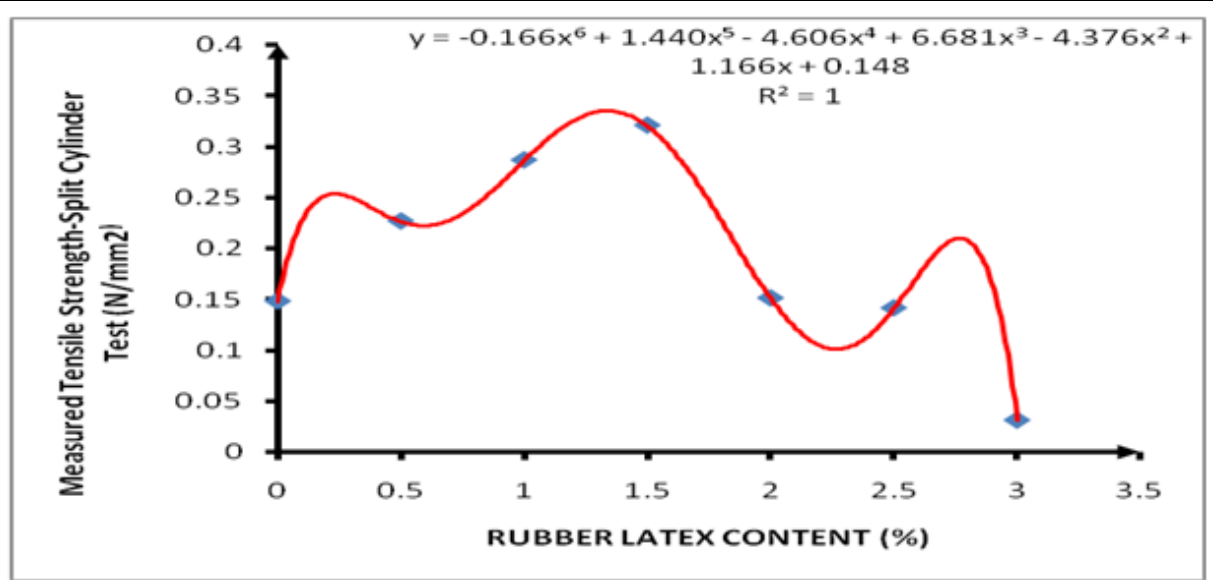

Figure1. Measured Tensile Strength from Split Cylinder Vs Rubber Latex Content

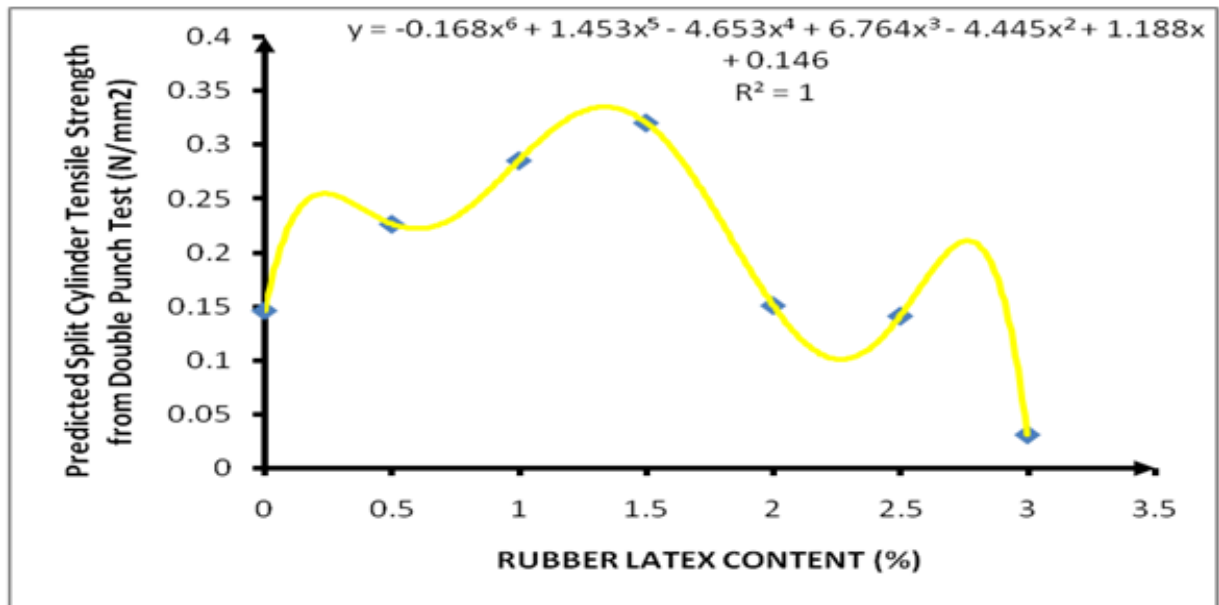

Figure2. Predicted Tensile Strength Vs Rubber Latex Content

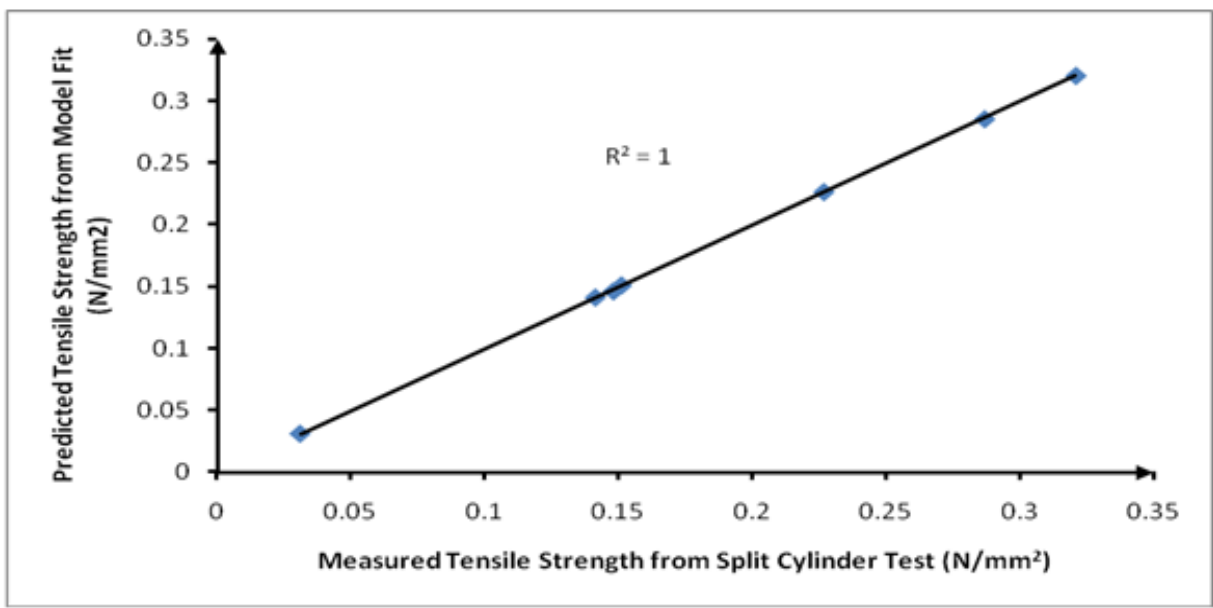

Figure3. Predicted Tensile Strength Vs Measured Tensile Strength from Split Test

In order to validate the fairness of the derived model the measured tensile strength values from laboratory tests was plotted on the same graph scale with the predicted tensile strength from correlation with double punch test from the laboratory (Equation 6). The results of their correlation revealed that the predicted tensile strength closely simulated the measured tensile strength with an $\mathrm{R}^{2}$ of 1 as presented in Figure 3 above.

\section{DisCuSSIONS}

From Figures $1 \& 2$, it was observed that both the measured and predicted tensile strength nearly exhibited the same characteristics under same conditions of rubber latex content.

Secondly, from Table 6 and Figure 3 the results of the predicted tensile strength of split cylinder from double punch test as in Equation (6) almost replicates the results of tensile strength of split cylinder measured from the laboratory. 


\section{Conclusions}

From the foregoing based on the laboratory experiments carried out, results obtained and analysis as presented in the sections above the following conclusions can be made;

1. Since the Derived Model for predicting tensile strength of split cylinder test from double punch from Equation (6) closely simulates results obtained from measured results of tensile strength of split cylinder from the laboratory it can thus be accepted as a means for predicting tensile strength of split cylinder test under similar conditions.

2. The general form of the Derived Model for predicting tensile strength for a split cylinder test from a double punch test can be written in simple terms as in equation 6 for a rubberized asphalt concrete.

\section{REFERENCES}

[1] Asphalt Institute (1981) “Thickness Design-Asphalt Pavements for Highways and Streets", Manual Series No. 1.

[2] Bonnot, J. (1986) "Asphalt Aggregate Mixtures", Transportation Research Record, 1096, Transportation Research Board, 42-51.

[3] Chen, W. F. (1968) "Extensibility of Concrete or Rock and The Theorems of Limit Analysis", Fritz Engineering Laboratory Report No. 356.5, Lehigh University, Bethlehem.

[4] Chen, W. F., (1969) "Double punch test for tensile strength of concrete, PB224770/AS (NTIS)", Fritz Laboratory Reports. Paper 1995.

[5] Chen, W. F. (1970) "Double Punch test for Tensile Strength of Concrete" ACI Journal, Proceedings V.67, No. 12, PP. 993-995

[6] Chen, W. F. and Yuan, R. L. (1980) “Tensile Strength of Concrete: Double Punch Test” Journal of American Society of Engineers, Structural Division, vol. 106, No. SI8, pp. 1673-1693.

[7] Davies, J.D. and Bose, D. K. (1968) "Stress Distribution in Splitting Tests", Journal of the American Concrete Institute, Proceedings, Vol. 65, No. 8, pp. 662-669.http://preserve.lehigh. edu/engr-civil-environmental-fritz-lab-reports/1995

[8] Draper N. R, Smith H (1998) “Applied Research Analysis, 3rd ed. John Wiley.

[9] Emesiobi, F. C. (2000) "Bitumen and Tars: Testing and Quality Control of Materials in Civil and Highway Engineering”, Port Harcourt, Nigeria, Blue Print Limited, pp. 182- 184.

[10] Igwe, E. A., Ayotamuno, M. J., Okparanma, R. N., Ogaji, S. O. T., and Probert, S. D., (2009) "Road Surface Properties affecting Rates of Energy Dissipation from Vehicles", Journal of Applied Energy, vol. 86, pp. 1692-1696, Elsevier Publishing.

[11] Malhotra, V. M. (1967) "Problems Associated with Determining The Tensile Strength on Concrete", Mines Branch Report, Department of Energy Mines and Resources, Ottawa, Canada, Vol. 10, No. A-6, Paper No. AIC-67-Civ-9, pp. 3 23.

[12] Mallick, R. B., and El-Korchi, T. (2013) "Pavement Engineering: Principles and Practice" second edition by Taylor \& Francis Group, CRC press, Boca Raton London New York.

[13] National Asphalt Pavement Association (1982) "Development of Marshall Procedures for Designing Asphalt Paving Mixtures", Information Series 84, National Asphalt Pavement Association Lanham, MD.

[14] Nilsson, S. (1961) "The Tensile Strength of Concrete determined by Splitting Tests on Cubes", Rilem Bulletin, No. 11 (New Series), pp. 63-67

[15] Ratkowsky, D. A. (1990) "Handbook of Non Linear Regression Models", Marcel Dekker

[16] Roberts, F. L. Kandhal, P. S., Brown, E. R.; Lee, D. Y. and Kennedy, T. W., (1996) "Hot Mix Asphalt Materials, Mixture Design, and Construction" National Asphalt Pavement

Association Education Foundation Lanham, MD.

[17] Seber, G. A. F. and Wild, C. J. (1989) "Non Linear Regression”, John Wiley

[18] Timoshonko, S. (1934) "Theory of Elasticity”, McGraw-Hill Book Company, New York, pp. 104-108.

[19] Wright, P. J. F. (1955) "Comments on an Indirect Tensile Test on Concrete Cylinders", Magazine of Concrete Research, London, Vol. 7, No. 20, pp. 87-96 July 1955. 
Enwuso A. Igwe et al.

\section{APPENDIX A: LiST OF TABLES}

Table1. Iteration History

\begin{tabular}{|l|l|l|l|}
\hline Iteration Number(a) & Residual Sum of Squares & Parameter \\
\hline & & $\mathrm{a}$ & $\mathrm{b}$ \\
\hline 0.1 & .000 & 1.170 & .009 \\
\hline 1.1 & .000 & 1.169 & .010 \\
\hline 2.1 & .000 & 1.169 & .009 \\
\hline 3.1 & .000 & 1.169 & .009 \\
\hline 4.1 & .000 & 1.166 & .007 \\
\hline 5.1 & .000 & 1.160 & .004 \\
\hline 6.1 & .000 & 1.153 & .000 \\
\hline 7.1 & .000 & 1.152 & .000 \\
\hline 8.1 & .000 & 1.152 & .000 \\
\hline 9.1 & .000 & 1.152 & $-6.22 \mathrm{E}-006$ \\
\hline 10.1 & .000 & 1.152 & $2.30 \mathrm{E}-006$ \\
\hline
\end{tabular}

Derivatives are calculated numerically.

a Major iteration number is displayed to the left of the decimal, and minor iteration number is to the right of the decimal.

b Run stopped after 10 iterations. Optimal solution is found.

Table2. Parameter Estimates

\begin{tabular}{|l|l|l|l|l|l|}
\hline & Parameter & Estimate & Std. Error & 95\% Confidence Interval \\
\hline & & & & Lower Bound & Upper Bound \\
\hline Asymptotic & a & 1.152 & .000 & 1.152 & 1.152 \\
\hline & b & $2.30 \mathrm{E}-006$ & .000 & $-3.57 \mathrm{E}-007$ & $4.95 \mathrm{E}-006$ \\
\hline Bootstrap & a & 1.152 & .000 & 1.152 & 1.152 \\
\hline & b & $2.30 \mathrm{E}-006$ & .000 & $1.94 \mathrm{E}-006$ & $2.65 \mathrm{E}-006$ \\
\hline
\end{tabular}

a Based on 30 samples.

$b$ Loss function value equals 1.67E-013.

Table3. Anova

\begin{tabular}{|l|l|l|l|}
\hline Source & Sum of Squares & df & Mean Squares \\
\hline Regression & .302 & 2 & .151 \\
\hline Residual & .000 & 5 & .000 \\
\hline Uncorrected Total & .302 & 7 & \\
\hline Corrected Total & .059 & 6 & \\
\hline
\end{tabular}

Dependent variable: SPLIT CYLINDER TENSILE STRENGTH

$R$ squared $=1-($ Residual Sum of Squares $) /($ Corrected Sum of Squares $)=1.000$. 